\section{A foundation for Africa}

\section{A research plan that has to be seen to be believed.}

N igeria’s plan to set up a multi-billion-dollar endowment for science (see Nature 442, 334; 2006) will be a tremendous boon for the development of science in Africa's most populous nation - if it comes to fruition.

President Olusegun Obasanjo's vow to set up an agency based on the US National Science Foundation (NSF) to distribute the endowment's surplus is welcome and far-sighted. Such an agency is necessary to ensure that the money is sensibly spent. The structure of the proposed agency will tell us whether its founders are serious about replicating the independence that is the NSF's hallmark.

The idea may not be as far-fetched as it sounds. The NSF was itself ingeniously designed to protect scientific funding decisions from the propensity of politicians to treat research cash as a slush fund to be shared out among the most powerful - exactly the problem that any attempt to support science in Nigeria will face.

The characteristics of the US agency are easy to recognize. It is managed by a board of prominent scientists, who serve for terms of six years. One-third of them rotate off every two years, so the board cannot readily be 'stacked' by an incoming US president. The director serves for up to six years too, unlocking the appointment from the president's four-year election cycle.

The staff of the agency is small and professional, and includes academics on secondment from universities. The staff set up advisory panels, often including international representation, in different subdisciplines and make decisions on grants. Nearly all the agency's budget goes on grants: there are no laboratories or permanent infrastructure to swallow the cash.

There are issues with transplanting this widely admired model, however. It works best where university professors are already on good salaries, as in the United States, and only need research grants to cover the direct costs of research itself.

UNESCO, which is working with Nigeria on its science policy, has suggested that about five of Nigeria's existing universities be selected for extra funding. That proposal, along with the endowment itself, will be considered by Nigeria's parliament this autumn. The president's advisers say they would like Nigeria to provide the bulk of the investment, with some assistance from foreign donors.

It may sound odd for Nigeria, with its buoyant oil revenues, to expect hard-pressed donor "President Obasanjo's vow to set up an agency based on the NSF to distribute the endowment's surplus is welcome and far-sighted." agencies to fund such a plan. But organizations such as the World Bank often invest in fostering long-term economic development and adding to the fund would give donors some say in how it is run.

Setting up a politically independent science agency with an endowment to ensure its long-term viability would be an eminently sensible use of windfall oil revenues. Long-term observers of the nation's politics will no doubt be sceptical. But if Obasanjo can pull it off before his expected departure next year, he would leave a spectacular legacy for science in Nigeria, and in all of Africa.

As a label, 'biochemistry' fails to do justice to this encroachment of chemistry into biology, being associated primarily with the study of enzyme kinetics. Similarly, chemists can now design materials from the atomic level upwards, whether they work in departments of chemical engineering, polymer science or materials. Chemists may even give electronic engineers a run for their money in creating self-assembling circuits and memories.

The problem is that so little of the credit falls on chemistry itself. 'Chemical biology', for example, presents the chemical aspect as an adjunct to another discipline, while a great deal of inventive chemistry comes under the umbrella of nanotechnology. This tendency is already reflected in university reshuffles, at Harvard and elsewhere, that might displace parts of chemistry to other departments.

Such rebranding is not the way to secure chemistry's position as an independent discipline. Neither will that be achieved merely by loudly trumpeting chemistry's considerable achievements. Chemistry needs, instead, to reassert itself as a core scientific discipline albeit one that is inherently interdisciplinary and has a strong applied component. Perhaps it is time for chemistry departments to rethink the subject's internal structure: the traditional divisions of physical, organic and inorganic chemistry have long since become irrelevant in many respects.

Another challenge for chemists is to be ambitious in defining the discipline's boundaries, particularly in relation to the life sciences. And in terms of public perception, chemistry has to find a way of establishing its centrality in the mysterious process we call life. 